\title{
ANALYSIS OF TSUNAMI EFFECT AND STRUCTURAL RESPONSE
}

\author{
Tiecheng Wang, Tao Meng, Hailong Zhao
}

Original scientific paper

Tsunami is one of the serious natural disasters in the world, which produce huge horizontal thrust on costal buildings, resulting in a large number of houses collapsed instantaneously, causing serious casualties and economic losses. In this paper, based on support from the hydrodynamic software FLOW-3D, the method of Volume of Fluid (VOF) is utilized to capture free interface, and the ideal solitary wave model is applied to simulate tsunami waves. Based on simulating and analysing the three-dimensional numerical model of reinforced concrete frame structure under the impact of tsunami waves, the magnitude and distribution of tsunami forces can be obtained. Moreover, the finite element analysis software ANSYS is adopted to set up finite element model for the frame structure, so as to analyse the response of the reinforced concrete frame structure under the impact of tsunami forces, and to put forward related structural countermeasures, engineering prevention and control measures to resist tsunami forces.

Keywords: tsunami disaster; tsunami forces; numerical simulation; structural response; prevention and control measures

\section{Analiza učinka tsunamija i reakcije konstrukcije}

Izvorni znanstveni članak Tsunami predstavlja jednu od ozbiljnih prirodnih katastrofa u svijetu, koja rezultira ogromnom horizontalnom potisnom silom na obalne zgrade, dovodeći do trenutnog urušavanja velikog broja zgrada što uzrokuje velike nesreće i ekonomske gubitke. U ovom radu, uz podršku hidrodinamičkog softvera FLOW-3D, primjenom metode Volumena fluida (VOF), zahvaćena je slobodna dodirna površina i primijenjen model idealnog pojedinačnog vala u svrhu simuliranja valova tsunamija. Zasnivajući se na simuliranju i analizi trodimenzijskog numeričkog modela okvira konstrukcije od armiranog betona pod udarnom silom tsunami valova, može se ustanoviti veličina i raspodjela sila tsunamija. Osim toga, primjenom softvera ANSYS za analizu konačnih elemenata, dobiven je model konačnih elemenata za konstrukciju okvira kako bi se analizirala reakcija konstrukcije od armiranog betona na udar tsunami sila te poduzele odgovarajuće konstrukcijske protumjere, tehničke preventivne i kontrolne mjere te tako oduprlo silama tsunamija.

Ključne riječi: katastrofa izazvana tsunamijem; tsunami sile; numerička simulacija; reakcija konstrukcije; preventivne i kontrolne mjere

\section{Introduction}

Tsunami is an intense and short-period motion of ocean water, mainly triggered by strong sea quake, underwater volcano eruption, as well as large-scale underwater or coastal landslide [1]. However, among the causes leading to tsunami, the sea quake is the most primary reason, specially the dip-slip type quake that staggers up and down along the fault surface. When traveling nearby the seabed, tsunami waves are unblocked, reaching thousands of kilometres with quite limited energy attenuation. However, when the waves travel to the shallow water areas, the wave velocity decreases rapidly, and the wave height increases sharply. Several meters or even decades of meters water wall is formed, which is almost identical from seabed to sea level. Large volumes of water with enormous energy rush towards coastal line, destroying and sweeping buildings, people and livestock instantly, and leading to massive casualties and property losses. Although the occurrence frequency of tsunami is very low, once it happens, it can bring uncountable disastrous consequence to human beings. The last decade has been witness to a number of major tsunamis that have resulted in catastrophic human and economic losses to coastal communities. (Indian Ocean 2004 [2-4], Chile 2010 [5-7], and Japan 2011 [89]). As for this, to analyse the magnitude and distribution of tsunami forces on the structure and to study the response of structure under the impact of tsunami forces has an important meaning in improving the performance of structure, resisting tsunami disaster, as well as reducing casualties and economic losses.

The occurrence frequency of tsunami is low. As a result, so far, there are not much research findings in this field. Until the $70 \mathrm{~s}$ to $80 \mathrm{~s}$ of the $20^{\text {th }}$ century, Goto, Imamura, et al. [10-12] proposed the tsunami numerical calculation model based on the finite difference method, which was designed to numerically simulate and analyse the occurring and propagating of tsunami. Houston (1978) et al. [13] utilized finite element method and simulated the 1960 Chile tsunami and 1964 Alaska tsunami. They also conducted spectral analysis on tsunami waves. Soon afterwards, Farrar and Houston [14] simulated the resonance influence of tsunami on Oahu Island and Barbers Island. Since the 1990s, National Science Foundation (NSF) has established a special fund to study tsunami numerical model. NOAA (National Oceanic and Atmospheric Administration) specially founded the NOAA Center for Tsunami Research, which developed MOST (Method of Splitting Tsunami) numerical model [15]. This numerical model can be applied to simulate the entire process of earthquake, tsunami wave propagation, and near shore wave run-up.

Currently, researches related to tsunami mainly concentrate on numerical simulation of tsunami wave propagation, early-warning of tsunami occurrence, and the impact of tsunami wave on a single structural component [16-23]. Yet, so far, there is no systematic study that focuses on the numerical simulation and structural response of three-dimensional building structure under the impact of tsunami waves. Actually, it is an important theoretical research method to numerically simulate and analyse the interaction between tsunami waves and structures, so as to figure out the response of structures under the impact of tsunami waves. This method is effective in complementing the defects of some experimental researches. In this paper, based on the computational fluid dynamics software of FLOW-3D, the 
method of Volume of Fluid (VOF)[24] is utilized to capture free interface, and the ideal solitary wave model is applied to simulate tsunami waves. Through simulating and analysing the three-dimensional numerical model of reinforced concrete frame structure under the impact of tsunami waves, the magnitude and distribution of tsunami forces can be ascertained.

\section{Numerical simulation of tsunami forces 2.1 Numerical simulation method}

Tsunami wave is a sort of long period gravity wave, and gravity is the restoring force. Gravity holds the tendency to restore the disturbed sea water back to the undisturbed state. When the gravity waves are propagating in the seawater, gravity can transfer wave energy from the excessive regions to the insufficient regions. Moreover, as sea water is incompressible, tsunami waves are also considered as an incompressible viscous fluid motion. FLOW-3D takes the continuity equation and the Navier-stokes equation for incompressible viscous fluid motion as the control equation for fluid motion. The equation expressions are listed as follows:

Continuity equation:

$$
\frac{\partial}{\partial x}\left(u A_{x}\right)+\frac{\partial}{\partial y}\left(v A_{y}\right)+\frac{\partial}{\partial z}\left(w A_{z}\right)=0
$$

Momentum equation:

$$
\left.\begin{array}{l}
\frac{\partial u}{\partial t}+\frac{1}{V_{\mathrm{F}}}\left(u A_{x} \frac{\partial u}{\partial x}+v A_{y} \frac{\partial u}{\partial y}+w A_{z} \frac{\partial u}{\partial z}\right)=-\frac{1}{\rho} \frac{\partial p}{\partial x}+G_{x}+f_{x} \\
\frac{\partial v}{\partial t}+\frac{1}{V_{\mathrm{F}}}\left(u A_{x} \frac{\partial v}{\partial x}+v A_{y} \frac{\partial v}{\partial y}+w A_{z} \frac{\partial v}{\partial z}\right)=-\frac{1}{\rho} \frac{\partial p}{\partial y}+G_{y}+f_{y} \\
\frac{\partial w}{\partial t}+\frac{1}{V_{\mathrm{F}}}\left(u A_{x} \frac{\partial w}{\partial x}+v A_{y} \frac{\partial w}{\partial y}+w A_{z} \frac{\partial w}{\partial z}\right)=-\frac{1}{\rho} \frac{\partial p}{\partial z}+G_{z}+f_{z}
\end{array}\right\}
$$

where $\rho$ refers to the density of fluid; $V_{\mathrm{F}}$ is the volume fraction of movable fluid; $A_{x}, A_{\mathrm{y}}$ and $A_{\mathrm{z}}$ represent the fractional areas open to flow along the three directions of $x, y$ and $z ; u, v$ and $w$ separately correspond to the velocity component of fluid along the directions of $x, y$ and $z$; $G_{x}$, $G_{y}$ and $G_{z}$ stand for the body acceleration of fluid along the directions of $x, y$ and $z ; f_{\mathrm{x}}, f_{\mathrm{y}}$ and $f_{\mathrm{z}}$ refer to the viscous acceleration of fluid along the three directions of $x, y$ and $z$.

\subsection{Model of tsunami impact on the structure}

When waves travel into near shore shallow water areas, the shape and motion of tsunami waves closing to breaking is quite similar to the solitary wave. By researching the propagating of tsunami waves, Hammack and Segur [25] pointed that, under the circumstance with positive net volume variation (such as unidirectional up of seabed), some solitary waves with stable shapes could be generated. As for this, the ideal solitary wave is employed to simulate tsunami wave in this paper. The propagation velocity of ideal solitary wave and tsunami wave in the ocean can be calculated by Eqs. (3) and (4) respectively:

$C=\sqrt{g(H+d)}$

where $g$ refers to the gravitational acceleration, $H$ represents the height of solitary wave, and $d$ indicates the depth of still water, in which the solitary wave travels.

$$
C=\sqrt{g h}
$$

where $h$ refers to the depth of sea water, in which the tsunami wave spreads. Similar to the ideal solitary wave, tsunami wave also has very long wave length and relatively small wave height. The propagation velocity may be calculated from the above two equations, which are determined by the depth of water.

All the wave profile of the ideal solitary wave is located above the surface of still water. Theoretically, the wave length is infinite. The shape of solitary wave is a single crest on balanced water level, with no other rise or fall before and behind the crest. The wave pattern may be described with Korteweg-de Vries equation [26]. The expression of wave profile $\eta$ is shown as follows:

$\eta=H \sec h^{2}\left[\sqrt{\frac{3 H}{4 d^{3}}}(x-C t)\right]$

By contrast, FLOW-3D tracks free interface with Volume of Fluid (VOF) method, so as to ascertain the location of the free interface, to form the border of the free surface, and to correctly simulate the fluctuation of the free surface.

In allusion to tsunami occurring in coastal areas, this paper makes use of FLOW-3D software and sets up the three-dimensional finite element model for tsunami wave interaction with a reinforced concrete frame structure in this area to analyse the magnitude and distribution of tsunami wave forces on the frame structure. On this basis, the tsunami forces acting on the frame structure are compared with earthquake's impact on the frame structure to propose structural and engineering prevention and control measures to resist tsunami load.

The seismic fortification intensity in this region is set as 8 , the basic design acceleration of ground is $0,2 \mathrm{~g}$. The height of tsunami wave that the frame structure suffers from is $5 \mathrm{~m}$. It can be calculated from Eq. (4) that the velocity of tsunami wave is $7 \mathrm{~m} / \mathrm{s}$. The structural form is reinforced concrete frame structure and the plane and elevation layout of the building is shown in Fig. 1. The concrete grade of the frame is $\mathrm{C} 30$, with the axial compressive strength to be $20,1 \mathrm{MPa}$. The longitudinal load-bearing bar adopts HRB335, with the standard yield strength to be $335 \mathrm{MPa}$. HPB300 is adopted for stirrups, with the standard yield strength to be $300 \mathrm{MPa}$. The size of structural grid is $6 \times 5 \mathrm{~m}$. The frame has 5 stories, and each story height of frame is $3 \mathrm{~m}$. The sectional dimension of column is $0,5 \times 0,5 \mathrm{~m}$. The impact direction of the tsunami wave is perpendicular to the longitudinal direction of the building that is the most disadvantageous 
impact direction and could generate the maximum forces on structure.

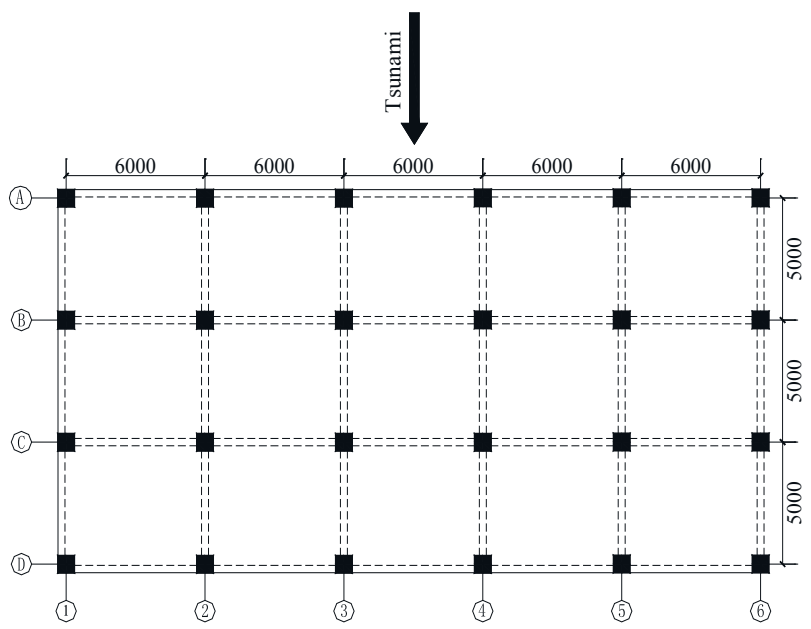

(a) Plane layout

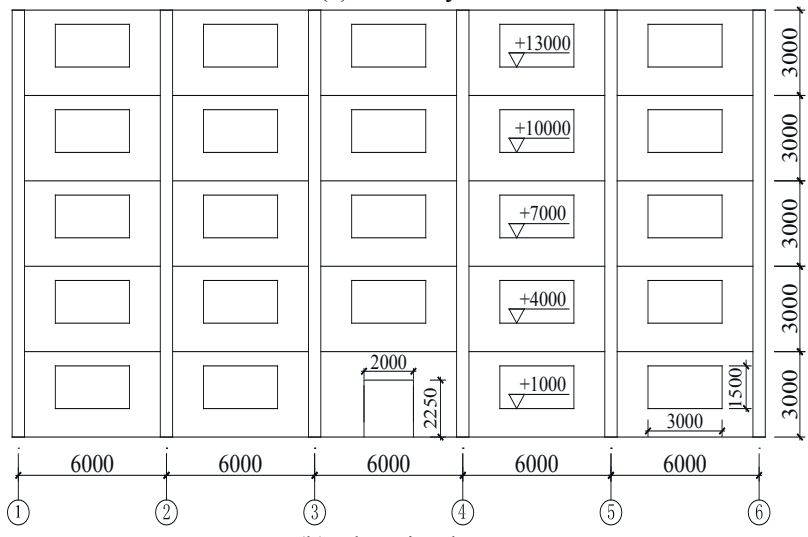

(b) Elevation layout

Figure 1 Plane and elevation layout of the structure (in $\mathrm{mm}$ )

The model constructed in this research is an incompressible and viscous flow model, and Newtonian viscosity with renormalized group (RNG) $k$ - $\varepsilon$ turbulence model was adopted. The boundary conditions and geometric dimension of the model are shown in Fig. 2. The left side is the entrance border (In Flow) of the incident wave. Based on the Eq. (3), its set as $H$ is equal to $2 \mathrm{~m}$ and the incident wave height $d$ is equal to $3 \mathrm{~m}$, therefore, the velocity of the incident wave is $7 \mathrm{~m} / \mathrm{s}$. The right side of the figure shows the exit border (Out Flow) of tsunami wave, which allows water to flow out freely. The up and down side of the figure were set as symmetry boundary condition. At the symmetry boundary, the flow flux of the fluid was zero and the tangential stress was 0 , i.e., the fluids at two sides of the symmetry boundary were continuous. The bed of the computational region of the model was set as no slip wall boundary condition, where the normal velocity of the fluid at this boundary was zero and did not allow the fluid to flow in or out. The other numerical input data were set as $1025 \mathrm{~kg} / \mathrm{m}^{3}$ for sea water density, $0,001 \mathrm{~Pa} \cdot \mathrm{s}$ for fluid viscosity and $9,81 \mathrm{~m} / \mathrm{s}^{2}$ for gravitational acceleration. In order to better simulate the motion of tsunami wave before impacting the structure, the influence of seaside slope on propagation of the tsunami wave is comprehensively considered. As for this, a $10 \%$ slope is set at the front side of the structure to simulate the coast.
This model is identical with the practical situation when the structure is impacted by tsunami waves.
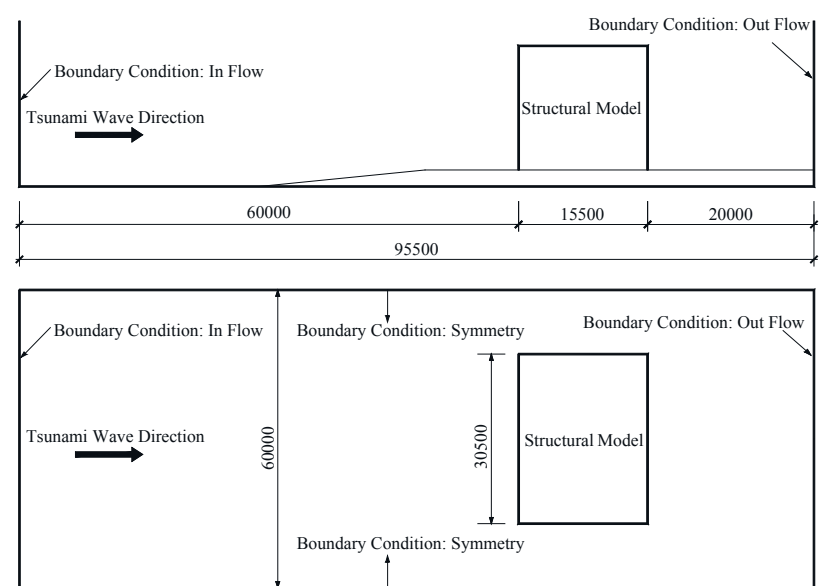

Figure 2 Model boundary condition and geometric dimension

In the simulation process, in order to compare the influence of tsunami wave on the structure separately with and without walls conditions at the upstream face at the bottom of the structure, the paper conducts simulation in two different cases. Case 1: The upstream face on the bottom floor of the building is constructed with walls, and the area ratio between holes and walls is $1: 4$, which is shown in Fig. 1(b). In the impacting process, the walls are not damaged, while the connection with the main structure is intact, as is shown in Fig. 3(a). Case 2: The upstream face on the bottom floor of the building has no walls. Floors from 2 to 5 are constructed with walls, and also the ratio between holes and walls is 1:4. In the impacting process, only columns on the bottom floor are bearing load from tsunami waves, as is shown in Fig. 3(b).

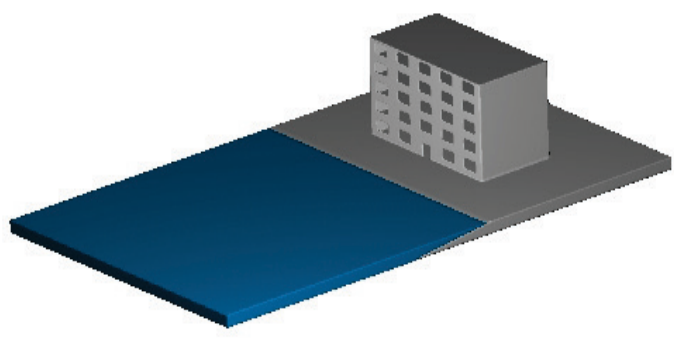

(a) Case 1

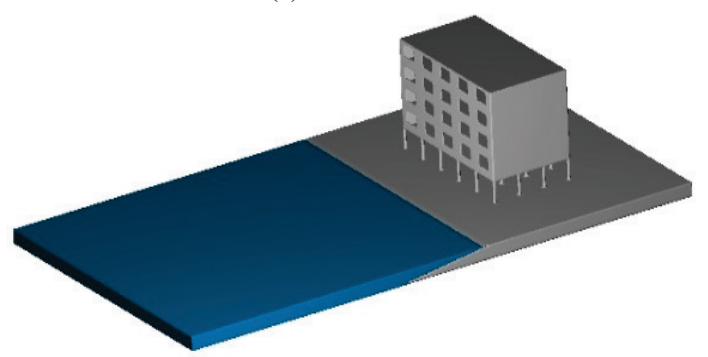

(b) Case 2

Figure 3 Finite Element Model

\subsection{Tsunami wave forces simulation results}

Based on simulation, Fig. 4 shows the time-history curves of tsunami wave horizontal thrust on the frame structure in Case 1 and Case 2. During the time period 
from $3,0 \mathrm{~s}$ to $6,5 \mathrm{~s}$ in Case 1 , the horizontal thrust of tsunami wave impacting on the structure presents a tendency of linear increment. After that, blocked by the upstream walls, local tsunami waves are reflected, so that tsunami load on the structure is reduced in a short period. Then, as the reflected wave gradually decreases, load on the structure increases gradually, which reaches the maximum value of $7909,6 \mathrm{kN}$ at $8,3 \mathrm{~s}$. At the moment, the tsunami wave reaches the largest run-up height and is strongly instable. After the tsunami wave reaches the largest run-up height, the load on the structure decreases sharply, which is finally stabilized at $12 \mathrm{~s}$. At the moment, the structure is in a stable state of being impacted by tsunami waves.

In Case 2, as the bottom of the structure is not constructed with upstream walls, there are only columns on the bottom floor to bear the impact from tsunami waves, so that the impacting area of the structure with tsunami waves is quite small. Before $9 \mathrm{~s}$, all loads generated from tsunami waves are impacting on columns of the bottom floor, and tsunami load on the structure increases gradually. Afterwards, the run-up height of tsunami waves increases continuously, and the upstream walls of the second floor start to contact with the tsunami waves. As for this, tsunami load on the structure takes on a rapid increment tendency, which is stabilized after $12 \mathrm{~s}$ and reaches the maximum value of $2129,2 \mathrm{kN}$ at $13,8 \mathrm{~s}$. When impacting with the structure in Case 2, tsunami waves encounter quite limited resistance, with small wave reflection. Thus, compared with the situation in Case 1, the variation amplitude of tsunami wave impacting on the structure in Case 2 is much more gentle.

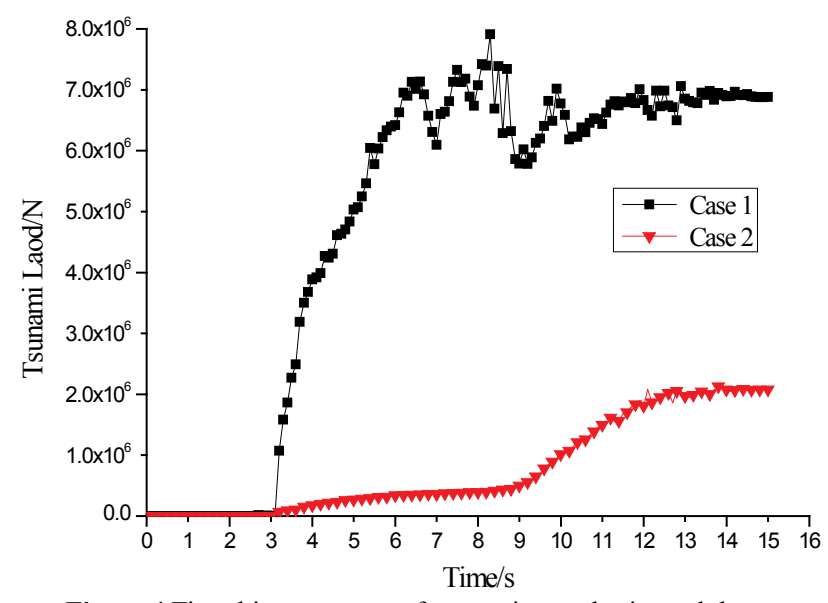

Figure 4 Time-history curves of tsunami wave horizontal thrust

The maximum tsunami wave force impacting on the structure in Case 2 is much less than that in Case 1. Moreover, the occurrence time of maximum tsunami wave force on the structure is later than that in Case 1. When no infilled wall is constructed on the upstream face of the bottom floor of the structure, there would be only columns on the bottom floor bearing the impact from tsunami waves, so that the resistance as water passes through the structure is smaller. Therefore, the structure in Case 2 is more effective in resisting tsunami waves, and that people in the structure would have more time to escape to the top or other higher positions.

\section{Non-linear analysis on the structure under tsunami forces}

\subsection{The Finite Element Model}

In order to figure out the deformation and damage of the structure under the impact of tsunami forces, ANSYS software is applied to conduct non-linear analysis on the structure which is impacted by the tsunami wave.

According to the different treatment of the steel bar in concrete, the finite element model of reinforced concrete is mainly comprised by three types: discrete type, integral type and composite type. As the structural model is quite large, the integral type finite element model is adopted for the convenience of calculation convergence. In other words, steel bars are continually and evenly distributed in the whole concrete element, with ribbed Solid 65 element to simulate the frame column. In the reinforced concrete frame structure, the rigidity of slab is very high, and its deformation is quite small when bearing horizontal load, so the slab can be regarded as a rigid body. In this paper, Shell 181 is applied to simulate rigid slab, and the finite element model of the structure is shown in Figure 5.

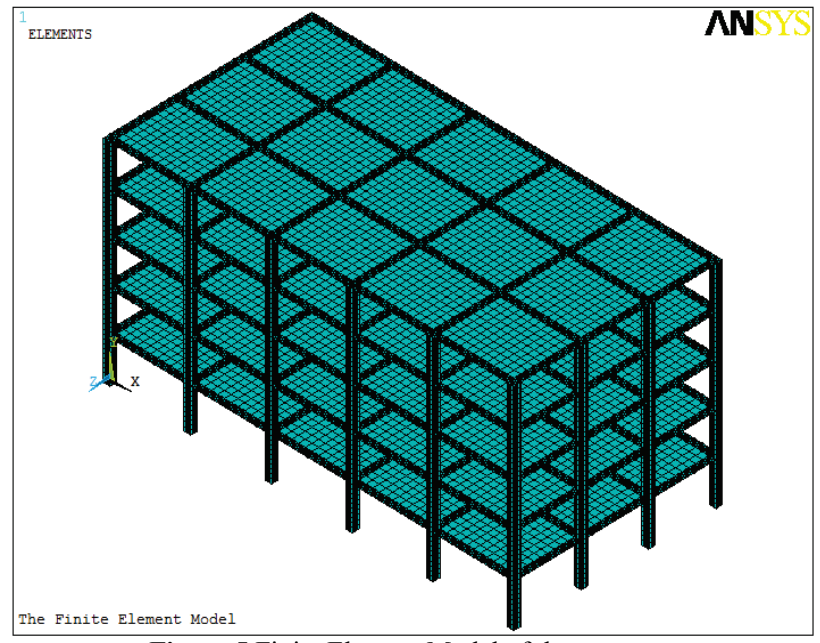

Figure 5 Finite Element Model of the structure

The stress-strain relationship of concrete under uniaxial compression in the finite element model of the structure adopts Multilinear Isotropic Hardening Plasticity (MISO) model. In order to guarantee the convergence of calculation, the descending branch of the concrete stressstrain relation curve is regarded as equivalent to a straight line. On this basis, the concrete constitutive relation proposed by Hongestad [27] is employed to realize the simulation. The mechanical model of the steel bar is to be simulated with Bilinear Isotropic Hardening Plasticity (BISO) model. The exact stress-strain relation curve for the material is shown in Fig. 6.

FEMA P646 [28] indicates the hydrodynamic forces are created by tsunami waves when the waves flow around the structure. Fig. 7 shows the distribution and the resultant force location of hydrodynamic forces on the structure or component in FEMA P646. It is shown from the diagram that hydrodynamic forces on the structure or component are evenly distributed along the inundation depth. When performing nonlinear analysis on the structure, the simulated tsunami wave force is regarded to 
be evenly distributed on the finite element model of the structure, and the maximum height of the load is $5 \mathrm{~m}$.

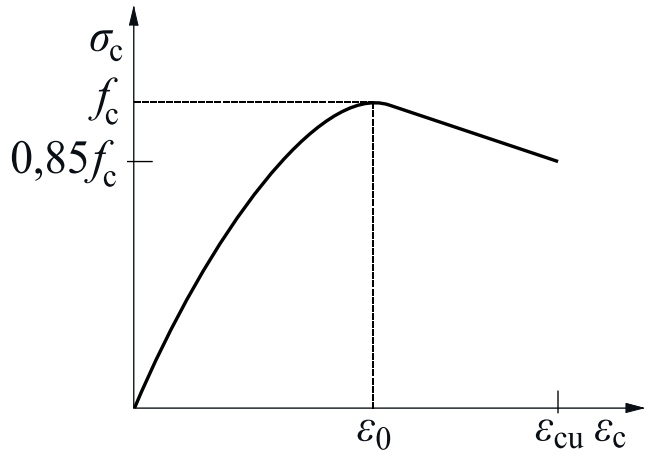

a) Concrete under uniaxial

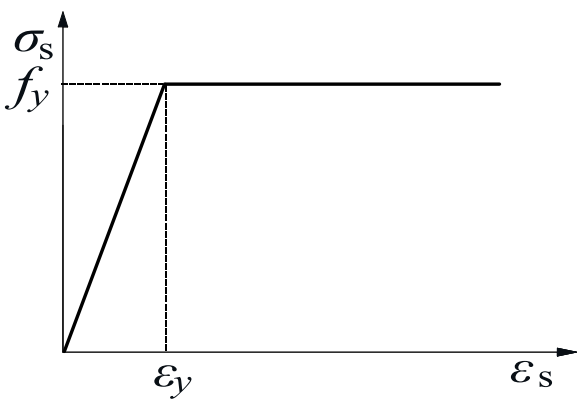

b) Steel bar compression

Figure 6 Material stress-strain relationship curve

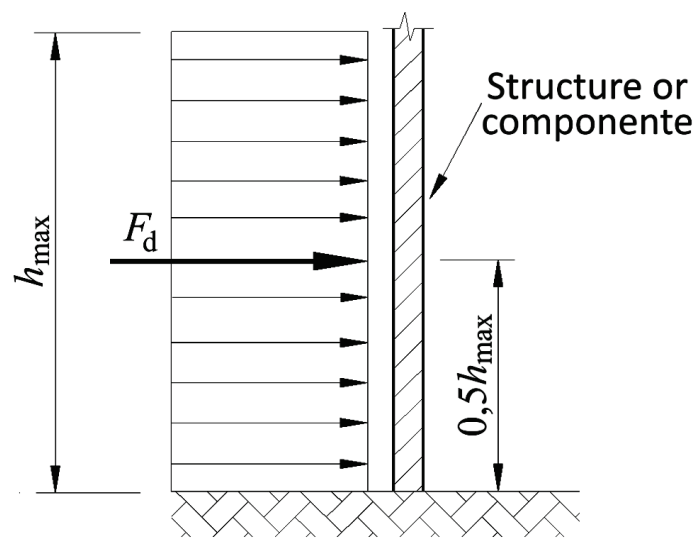

Figure 7 Hydrodynamic forces distribution and location of resultant force

In Case 1, as the walls and columns bear forces at the same time, the hydrodynamic forces impacting on the structure are evenly distributed on each column, and the load value is $0,1318 \mathrm{~N} / \mathrm{mm}^{2}$. The exact locations of the load are shown in Fig. 8. In Case 2, as the bottom floor has no walls and the second floor is arranged with walls, according to FEMA P646, we can find out the value of the hydrodynamic forces is influenced by the contact area between the building component and water. Therefore, based on the proportional relation between the area of upstream columns on the bottom floor and the area of upstream walls on the second floor, the hydrodynamic forces on columns of the bottom and second floor can be calculated by using this method. Finally, in Case 2, the uniformly distributed load of columns on the bottom floor is $0,02826 \mathrm{~N} / \mathrm{mm}^{2}$, and the uniformly distributed load of columns on the second floor is $0,04926 \mathrm{~N} / \mathrm{mm}^{2}$. The exact locations of the load are shown in Fig. 9.

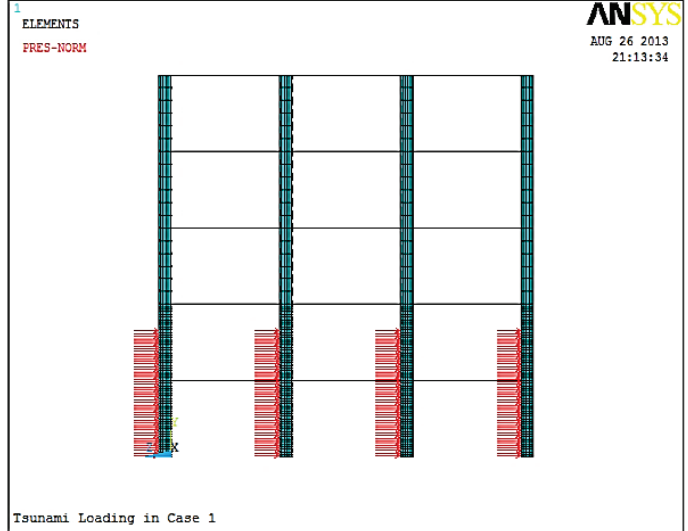

Figure 8 Hydrodynamic forces distribution on the structure in Case 1

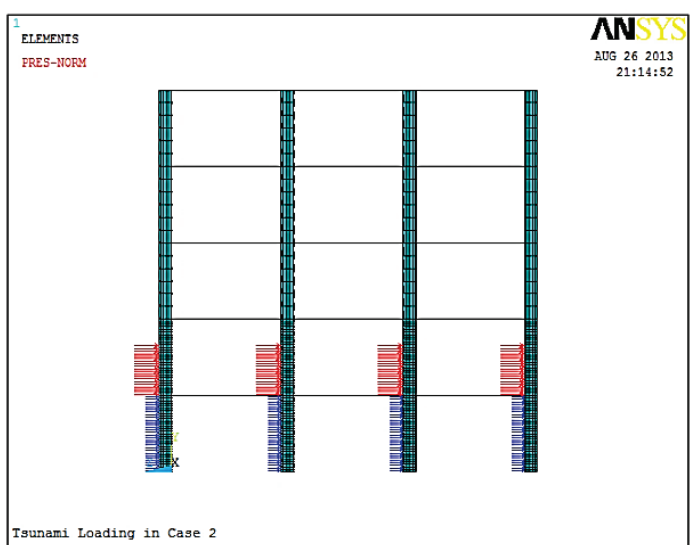

Figure 9 Hydrodynamic forces distribution on the structure in Case 2

\subsection{Nonlinear analysis results}

Through the finite element analysis, it is calculated that the maximum lateral displacement of the structure in Case 1 is $15,20 \mathrm{~mm}$ and in Case 2 is $4,37 \mathrm{~mm}$, which is shown in Figure 10. Thus, it is proved that the maximum lateral displacement in Case 1 is approximately 3,5 times larger than that in Case 2. It can be seen from the results that, under the same tsunami waves, Case 2 is more effective in reducing the impact of tsunami wave on the structure, which can help to improve the structure's performance in resisting tsunami. Demonstrated by the lateral deformation of the structure, during the impacting process, only the part directly contracting with sea water may be impacted by tsunami load, while the part above water is not influenced. As for this, tsunami load is partial structural load. In anti-tsunami design for structures, the strength of bottom component should be enhanced, so as to improve the performance of a structure to resist tsunami load.

The maximum stress and strain of steel bars at the bottom of columns on the first floor of the structure can be obtained by using the ANSYS element table, and the exact values are shown in Table 1 . From the table, it can be found that in Case 1, the maximum stress and strain of longitudinal reinforcement on the bottom floor have reached the yield strength of $335,00 \mathrm{MPa}$. At the moment, the structure is unsafe. By contrast, the maximum stress and strain of longitudinal reinforcement on the bottom floor are much smaller in Case 2, just only 126,79 MPa. The reinforcement is not yielding and the structure is safe in Case 2. 


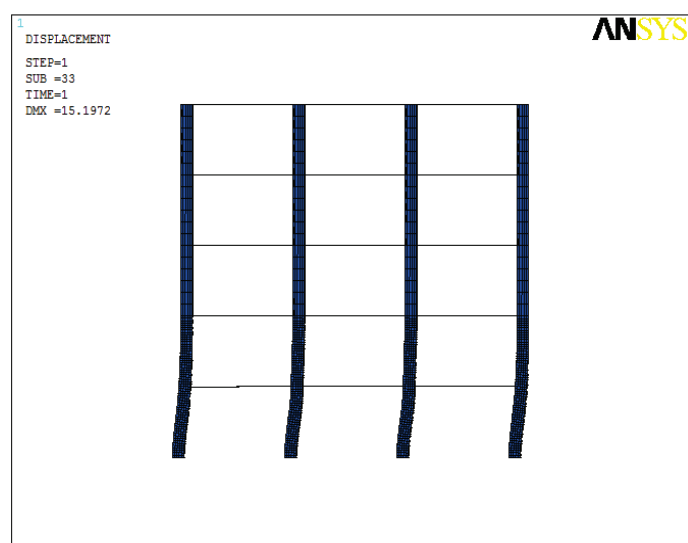

(a) Case 1

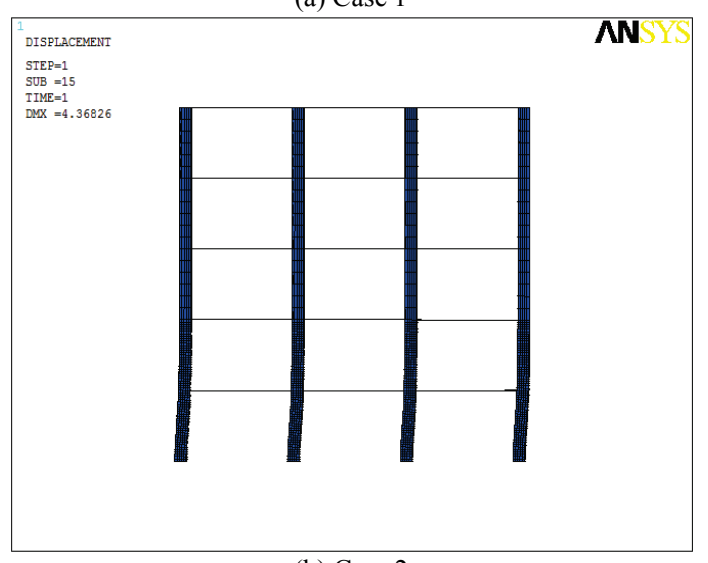

(b) Case 2

Figure 10 Lateral displacement of structure
Table 1 Longitudinal Reinforcement Stress of the Structure

\begin{tabular}{|c|c|c|}
\hline Cases & $\begin{array}{c}\text { Maximum tensile stress } \\
(\mathrm{MPa})\end{array}$ & $\begin{array}{c}\text { Maximum compressive } \\
\text { stress }(\mathrm{MPa})\end{array}$ \\
\hline 1 & 335,00 & 198,51 \\
\hline 2 & 126,79 & 67,23 \\
\hline
\end{tabular}

Comparing the different influence of earthquake and tsunami on the structure, the structure design software SAP2000 is used to analyse the response of the structure under earthquake, so as to calculate the maximum shearing force at the bottom of the structure, the earthquake's overturning moment on the structure and the maximum lateral displacement of the structure. The comparisons of the structure responses under the influence of earthquake and tsunami are listed in Tab. 2 respectively.

It is shown from Tab. 2 that, in Case 1, the base shear generated from tsunami is much larger than that generated from earthquake. By contrast, in Case 2, the base shear generated from tsunami is smaller than that generated from earthquake. The location of the resultant force caused by tsunami load is lower so that its overturning moment is smaller than that caused by earthquake in both Case 1 and Case 2. Eventually, the maximum lateral displacement of the structure caused by the tsunami in Case 1 is larger than that caused by an earthquake, however, the maximum lateral displacement of the structure caused by the tsunami in Case 2 is obviously smaller than that caused by an earthquake.

Table 2 Comparisons of the Structure Responses under Earthquake and Tsunami

\begin{tabular}{|c|c|c|c|c|c|c|}
\hline \multirow{2}{*}{ Cases } & \multicolumn{2}{|c|}{ Base Shear $(\mathrm{kN})$} & \multicolumn{2}{c|}{ Overturning Moment $(\mathrm{kN} \cdot \mathrm{m})$} & \multicolumn{2}{c|}{ Maximum Lateral Displacement (mm) } \\
\cline { 2 - 7 } & Tsunami & Earthquake & Tsunami & Earthquake & Tsunami & 15,20 \\
\hline 1 & 7909,6 & 3885,6 & 19774,0 & 28156,6 & 13,75 \\
\hline 2 & 2129,2 & 3885,6 & 6150,9 & 28156,6 & 4,37 & 13,75 \\
\hline
\end{tabular}

In conclusion, in order to reduce the tsunami wave forces acting on the structure, taking into consideration the structural feature of buildings, houses with structural forms which could resist tsunami should be constructed. When constructing houses in areas exposed to tsunami hazard, the engineering prevention and control measures should be taken, for example, upstream walls should not be arranged excessively at the bottom of the house, and the bottom layer should be designed into the open and transparent type, which can help to shunt tsunami waves, to reduce the impact of tsunami wave on the structure, and to improve the load-bearing ability of the structure.

\section{Conclusions}

(1) Based on the hydrodynamic software of FLOW$3 \mathrm{D}$, the method of Volume of Fluid (VOF) is utilized to capture free interface, and the ideal solitary wave model is applied to simulate tsunami waves. On this basis, threedimensional numerical simulation and analysis are performed in allusion to tsunami wave force impacting on a reinforced concrete frame, so as to ascertain the magnitude of tsunami wave force on the structure.

(2) It is proved by the result of numerical simulation of tsunami wave force, in order to reduce the tsunami wave forces acting on structure, houses with structural forms which could resist tsunami should be constructed. For example, upstream walls should not be arranged excessively at the bottom of the house, and the bottom layer should be designed into the open and transparent type, which can help to shunt tsunami waves, to reduce the impact of tsunami wave on the structure, and to improve the load-bearing ability of the structure. Moreover, tsunami load is local structural load, so that in anti-tsunami design, the strength of bottom components should be increased to improve the load-bearing ability of the structure.

(3) Finite element model of the structure under the impact of tsunami wave force is set up, with the objective to conduct nonlinear finite element static analysis on the structure. According to the analysis results, influenced by $5 \mathrm{~m}$ tsunami wave and in Case 1, the maximum tensile stress of longitudinal reinforcement on the bottom floor has reached the maximum yield strength and the structure is unsafe. In Case 2, the maximum tensile stress of longitudinal reinforcement on the bottom floor is much smaller, the reinforcement is not yielding and the structure is safe.

(4) The paper conducts a nonlinear finite element static analysis on the structure impacted by tsunami waves. Tsunami waves move at high speed, so that the impact on the structure is similar to the impulse force, 
causing dynamic amplification effect on the structure. As for this, analysis should be performed to research the dynamic response of the structure under tsunami waves.

\section{Acknowledgements}

Thanks for the contribution of my partners Zhijian Yang, Wenjin Wang, Qingwei Chen and Xiao Liu to this article.

\section{References}

[1] National Oceanic and Atmospheric Administration. // Designing for Tsunamis Background Papers, 2001.

[2] Risk Management Solutions; Managing Tsunami Risk in the Aftermath of the 2004 Indian Ocean Earthquake \& Tsunami, report by RMS, Newark, CA. USA, 2006.

[3] Nakano, Y. Design Load Evaluation for Tsunami Shelters Based on Damage Observations after Indian Ocean Tsunami Disaster due to The 2004 Sumatra Earthquake. // International Journal of the Tsunami Society. 29, 1(2010), pp. 11-20.

[4] Palermo, D.; Nistor, I.; Nouri, Y. Structural Failure Mechanisms and Forces Associated with Tsunami Loading. // Canadian Society of Civil Engineering CSCE, Quebec City, Canada, 10-13(2008), pp. 10.

[5] Lagos, M.; Arcas, D.; Ramirez, T.; Severino, R.; Garcia, C. Alturas de tsunami modelas y observadas. Evento del $27 \mathrm{de}$ Febrero de 2010. Chile/Resultados Preliminares.

[6] Fritz, H. M.; Petroff, C. M.; Catalán, P. A.; Cienfuegos, R.; Winckler, P. Field survey of the 27 February 2010 Chile tsunami. // Pure and Applied Geophysics. 168, 11(2011), pp. 1989-2010. DOI: 10.1007/s00024-011-0283-5

[7] Palermo, D.; Nistor, I.; Cornett, A.; Al-Faesly, T. Tsunami Impact on Near-Shore Infrastructure: Challenges and Solutions. // Canadian Civil Engineer, CSCE, Spring, 28, 2(2011), pp. 12-15.

[8] Chock, G.; Robertson, I.; Kriebel, D.; Francis, M.; Nistor, I. Tohoku Japan Tsunami of March 11, 2011 - Performance of Structures, Final Report, ASCE, 2012.

[9] Nistor, I.; Palermo, D.; Al-Faesly, T.; Cornett, A. Investigations and Experimental Modelling of the TsunamiInduced Extreme Hydrodynamic Forces on Structures. // $34^{\text {th }}$ International Association of Hydraulic Engineering (IAHR) Congress, Brisbane, Australia, July, 2011.

[10] Imamura, F.; Goto, C. Truncation error in numerical tsunami simulation by the finite difference method. // Coastal Engineering, JSCE31, 374, (1988), pp. 245-263.

[11] Goto, C.; Ogawa, Y. Tsunami numerical simulation with leapfrog scheme, Tohoku University, 52, 1982.

[12] Imamura, F.; Nagano, O.; Goto, C.; Shuto, N. Numerical simulation of transoceanic propagation of 1960 Chilean tsunami. // Proc. $34^{\text {th }}$ Japanese Conf. Coastal Eng. 34, 1987, pp. 172-176.

[13] Houston, J. R. Interaction of tsunamis with the Hawaiian Islands calculated by a finite element numerical model. // Journal of Physical Oceanography. 8, 1(1987), pp. 93-102. DOI: 10.1175/1520-0485(1978)008<0093:IOTWTH>2.0.CO;2

[14] Farrar, P. D.; Houston, J. R. Tsunami response of Barbers Point Harbor, Hawaii. WES Miscellaneous Paper HL-82-1, 1982.

[15] Titov, V.; González, F. I. Implementation and testing of the Method of Splitting Tsunami (MOST) model. US Department of Commerce, National Oceanic and Atmospheric Administration, Environmental Research Laboratories, Pacific Marine Environmental Laboratory, 1997.

[16] Ramsden, J. D.; Raichlen, F. Forces on Vertical Wall caused by Incident Bores. // Journal of Waterway, Port,
Coastal and Ocean Engineering, ASCE. 116, 5(1990), pp. 592-613.

[17] Ramsden, J. D. Forces on a vertical wall due to long waves, bores, and dry-bed surges. // Journal of Waterway, Port, Coastal and Ocean Engineering. 122, 3(1996), pp. 134-141. DOI: 10.1061/(ASCE)0733-950X(1996)122:3(134)

[18] Arnason, H. Interactions between an incident bore and a freestanding coastal structure [ph. D. thesis], University of Washington, Seattle, Wash, 2005.

[19] Arikawa, T. Behaviors of concrete walls under impulsive Tsunami load. // AGU Fall Meeting Abstracts, 2008, pp. $1: 1331$.

[20] Arikawa, T. Structural behavior under impulsive tsunami loading. // Journal of Disaster Research. 4, 6(2009), pp. 377-381.

[21] Lukkunaprasit, Panitan; Thanasisathit, Nuttawut; Yeh, Harry. Experimental Verification of FEMA P646 Tsunami Loading. // Journal of Disaster Research. 4, 6(2009), pp. 410-418.

[22] Al-Faesly, T.; Palermo, D.; Nistor, I. et al. Experimental modeling of extreme hydrodynamic forces on structural models. // International Journal of Protective Structures. 3, 4(2012), pp. 477-506. DOI: 10.1260/2041-4196.3.4.477

[23] Linton, D.; Gupta, R.; Cox, D. et al. Evaluation of Tsunami Loads on Wood-Frame Walls at Full Scale. // Journal of Structural Engineering. 139, 8(2012), pp. 1318-1325. DOl: 10.1061/(ASCE)ST.1943-541X.0000644

[24] Hirt, C. W.; Nicholas, B. D. Volume of Fluid (VOF) Method for the Dynamics of Free Boundaries. // Journal of Computational Physics. 39, (1981), pp.201-225. DOl: 10.1016/0021-9991(81)90145-5

[25] Hammack, J. L.; Segur, H. The Korteweg-devries Equation and Water aves, Part 2, Comparison with Experiments. // Journal of Fluid Mechanics. 65, (1974), pp. 289-314. DOI: 10.1017/S002211207400139X

[26] Choi, B H.; Kim, D C.; Pelinovsky, E. et al. Threedimensional simulation of tsunami run-up around conical island. // Coastal Engineering. 54, 8(2007), pp. 618-629. DOI: 10.1016/j.coastaleng.2007.02.001

[27] Hognested, E. Concrete Stress Distribution in Ultimate Strength Design, ACI, 1995, pp. 455-479.

[28] FEMA P646: Guidelines for Design of Structures for Vertical Evacuation from Tsunamis, Federal Emergency Management Agency, Washington, D. C., 2008.

\section{Authors' addresses}

Tiecheng Wang, professor

School of Civil Engineering, Tianjin University,

Key Laboratory of Coast Civil Structure Safety (Tianjin University), Ministry of Education,

92 Weijin Road, Nankai District, Tianjin, 300072, China E-mail: tcwang2010@126.com

Tao Meng, Ph.D.

School of Civil Engineering, Tianjin University 92 Weijin Road, Nankai District, Tianjin, 300072, China E-mail:mengtao@tju.edu.cn

Hailong Zhao, Lecturer, Corresponding author School of Civil Engineering, Tianjin University, Key Laboratory of Coast Civil Structure Safety (Tianjin University), Ministry of Education, 92 Weijin Road, Nankai District, Tianjin, 300072, China E-mail: hlongzhao@126.com 